\title{
Spontaneous Infarction in a Fibroadenoma of the Breast
}

\author{
Hatice Toy ${ }^{a}$ Hacı H. Esen ${ }^{a}$ Fatma C. Sonmez ${ }^{a}$ Tevfik Kucukkartallar ${ }^{b}$ \\ ${ }^{a}$ Department of Pathology, ${ }^{b}$ General Surgery, Meram Medical School, Selcuk University, Konya, Turkey
}

Keywords

Fibroadenoma $\cdot$ Infarction $\cdot$ Breast

\section{Summary}

Background: Fibroadenomas are common neoplasms in young women but occur in a wide age range from adolescent females to octogenians. Case Report: A 21-year-old female patient presented with a 10 -week history of a mass in her breast. Ultrasound examination demonstrated a $3.5 \times 3 \mathrm{~cm}$, well-circumscribed, semisolid mass. An excisional biopsy but no fine needle aspiration was performed. The patient had no history of pregnancy or lactation, or trauma or infection to the area of the lesion. The histopathological examination showed a spontaneously infarcted fibroadenoma. Conclusions: Spontaneous infarction is an uncommon complication in fibroadenoma of the breast, and there are very few reported cases in the literature.

\section{Introduction}

Fibroadenomas are common neoplasms in young women but occur in a wide age range from adolescent females to octogenians. Characteristically, fibroadenomas are sharply demarcated from the surrounding tissue and often appear encapsulated. They generally measure $2-3 \mathrm{~cm}$ in size but may become very large. The cut surface of the tumor is bulging, firm, and white; this appearance varies, however, depending on the amount of hyalinization and myxoid change [1]. In a typical fibroadenoma, both the epithelial and the mesenchymal elements are benign. Fibroadenoma consist of a combined proliferation of epithelial and mesenchymal elements. The stroma proliferates around tubular (pericanalicular) or compressed cleft-like (intracanalicular) ducts [1]. Spontaneous infarction occurs in about $0.5-1.5 \%$ of fibroadenoma cases, predominantly in young females during pregnancy or lactation [2]. Cases about infarction following fine needle aspiration are reported in the literature [3-6]. We report the histopathological findings of a case of spontaneous infarction

\section{Schlüsselwörter \\ Fibroadenom · Infarkt · Brust}

\section{Zusammenfassung}

Hintergrund: Fibroadenome treten gehäuft bei jungen Frauen auf, grundsätzlich können aber Frauen aller Altersgruppen (Teenager bis 80-90-Jährige) betroffen sein. Fallbericht: Eine 21-jährige Patientin wurde mit einer seit 10 Wochen bestehenden Vergrößerung der Brust vorstellig. Die Ultraschalluntersuchung ergab einen 3,5 $\times 3 \mathrm{~cm}$, gut umschriebenen, halbfesten Knoten. Es wurde eine Exzisionsbiopsie aber keine Feinnadelaspiration durchgeführt. In der Vorgeschichte der Patientin gab es keine Schwangerschaft bzw. Stillperiode, und im Bereich des Knotens war es weder zu einem Trauma noch einer Infektion gekommen. Die histopathologische Untersuchung ergab ein spontan infarziertes Fibroadenom. Schlussfolgerungen: Ein spontaner Infarkt ist eine seltene Komplikation bei Fibroadenomen der Brust, und es gibt nur wenige entsprechende Fallberichte in der Literatur.

of a fibroadenoma in a patient with no etiologic factors such as physiologic changes, trauma, or fine needle aspiration.

\section{Case Report}

A 21-year-old female patient presented with a 10-week history of a mass in the centro-lateral area of her right breast. There was no history of physiologic changes such as pregnancy or lactation, or infection or trauma to her breast. She did not experience pain or other symptoms. No fine needle aspiration was performed on the mass in her breast. Ultrasound examination demonstrated a $3.5 \times 3 \mathrm{~cm}$, well-circumscribed, semisolid mass in the centro-lateral area of the right breast, and a diagnosis of fibroadenoma was suggested. An excisional biopsy was performed. Gross examination of the specimen showed a $3.5 \times 3 \times 2.5 \mathrm{~cm}$, round, wellencapsulated mass which was white in color but featured a large, brown, hemorrhagic area in the center of the cut surface (fig. 1). Histopathologically, the lesion was encapsulated and had a viably rim of fibroadenoma with fibrous stroma, and cystic and cleft-like ducts at the periphery of necrotic and hemorrhagic areas. Within the necrotic and hemorrhagic areas, ducts filled with desquamated epithelial cells, congested large vessels, and inflammatory cells (neutrophils and macrophages) were seen. There was no evidence of thrombo-occlusive or inflammatory vascular

\section{KARGER}

Fax +497614520714

Information@Karger.de

www.karger.com (c) 2011 S. Karger GmbH, Freiburg

$1661-3791 / 11 / 0061-0054 \$ 38.00 / 0$

Accessible online at:

www.karger.com/brc
Hatice Toy, MD

Selcuk University

Meram Medical School, Department of Pathology

42080 Meram, Konya, Turkey

Tel. + 903322236982

haticetoy@hotmail.com 


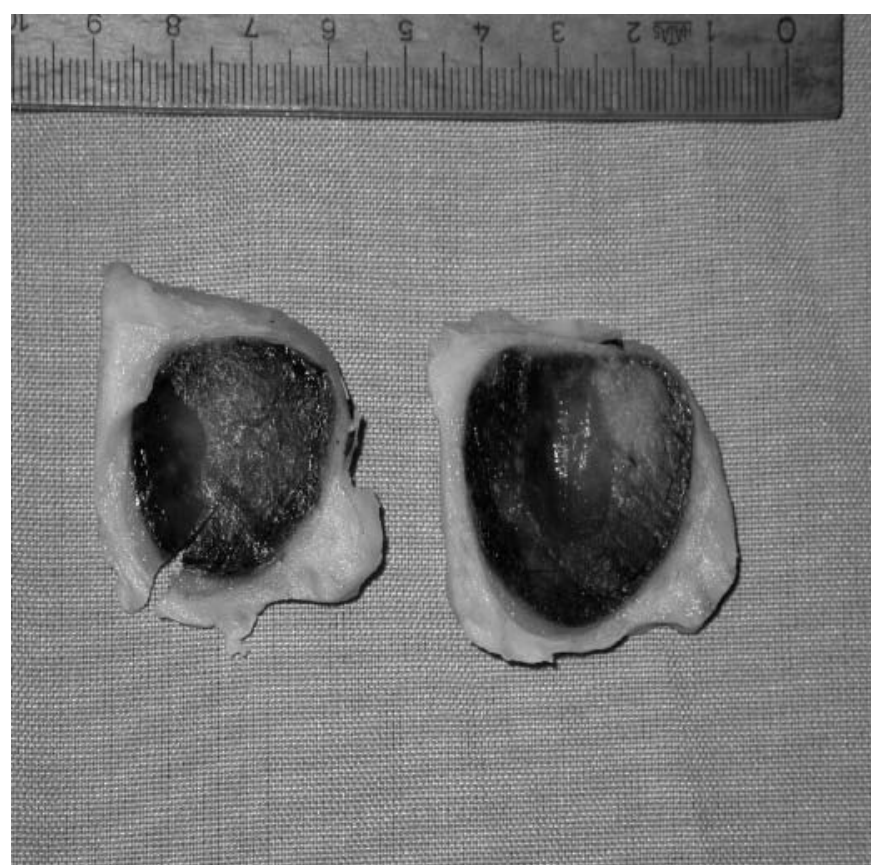

Fig. 1. Macroscopic view of the infarcted fibroadenoma.

disease (fig. 2). A histological diagnosis of 'fibroadenoma with infarction' was made.

\section{Discussion}

Fibroadenoma is the third most common lesion of the breast following fibrocystic changes and carcinoma, and constitutes about $20 \%$ of all benign breast lumps [1,7]. Fibroadenoma occurs most often in women of childbearing age; it is the most frequently observed neoplasm in women younger than age 25 . In Haagensen's review of fibroadenomas, the incidence of spontaneous infarction was $0.5 \%$ (5 in 1,000 cases), 3 of the patients were pregnant or lactating. Two cases of infarction associated with trombo-occlusive vascular changes in the feeding vessels were documented by Newman and Kohn [1] Infarction following fine needle aspiration has been reported [3-6].

On clinical examination, an infarcted fibroadenoma is likely to be mistaken for an inflammatory lesion because of

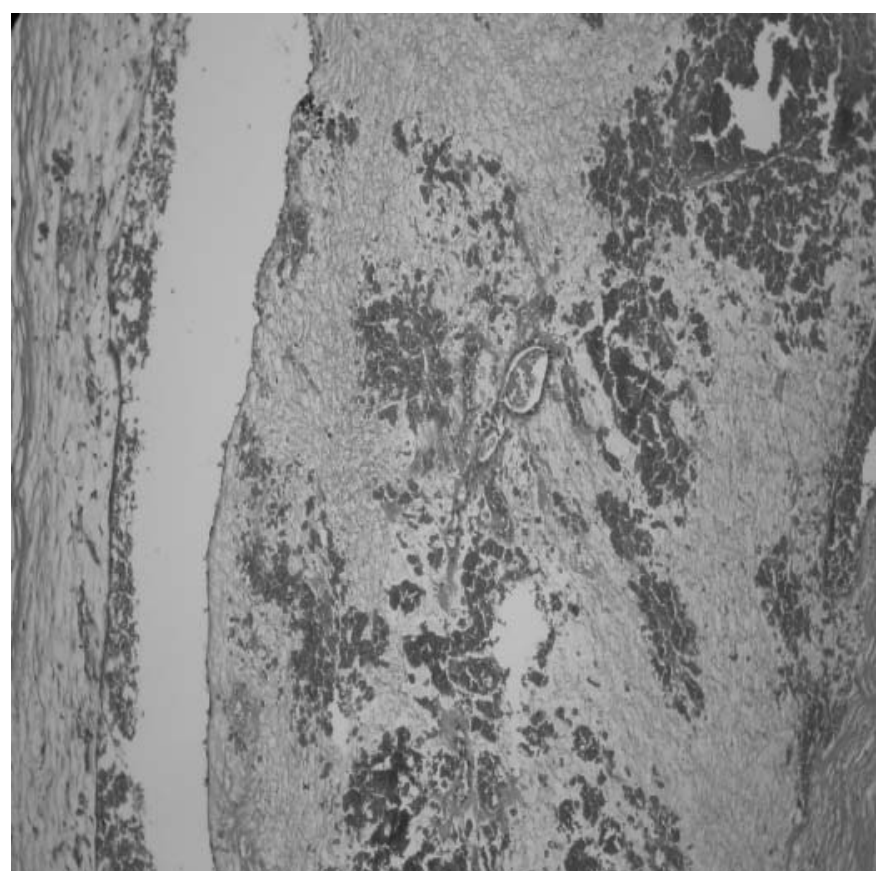

Fig. 2. Microscopic view of the infarcted fibroadenoma $(\times 100$, hematoxylin-eosin).

rapid enlargement with pain and tenderness, or for carcinoma because of fixation of the mass and lymphadenopathy [8-10]. On fine needle aspiration cytology, infarcted fibroadenoma needs to be differentiated from mastitis, duct ectasia, and even carcinoma. On frozen section and histological examination, these lesions are confused with carcinoma because of necrosis and ghost epithelial cells [11]. In some cases, speculations have been made about the possible role of mechanical factors since fibroadenomas are usually very mobile and could theoretically undergo torsion compromising bloody supply. If this was an important etiological factor, it is surprising that infarction is not a more frequent complication of fibroadenoma [8]. There are some conditions of the breast that can be complicated by infarction, such as intraductal papilloma, phylloides tumor, and sporadic cases occurring in patients who are on anticoagulant drugs [11]. We report a case that has no etiologic factors aiding infarction, hence it is a spontaneous infarction in a fibroadenoma of the breast. It is an uncommon complication, and there are very few such cases reported in the literature.

\section{References}

1 Tavassoli FA: Pathology of the Breast, 2nd ed. New York, NY, McGraw Hill, 1999, pp 571-9.

$\checkmark 2$ Fowler CL: Spontaneous infarction of fibroadenoma in an adolescent girl. Pediatr Radio 2004:34:988-90.

3 McCutheon JM, Lipa M: Infarction of a fibroadenoma of breast following fine needle aspiration. Cytopathology 1993;4:247-50.

$\checkmark 4$ Raju GC, Naraynsingh V: Infarction of fibroadenoma of the breast. J Royal Coll Surg Edinb $1985 ; 30 ; 162-63$.
5 Pinto RG, Couto F, Mandreker S: Infarction after fine needle aspiration. A report of four cases Acta Cytol 1996;40:739-41.

6 Vargas MP, Merino MJ: Infarcted myxoid fibroadenoma following fine-needle aspiration. Arch Pathol Lab Med 1996;120:1069-71.

7 Hughes LE, Mansel RE, Webster DJT: Fibroadenoma and related tumours; in Hughes LE, Mansel RE, Webster DJT (eds): Benign Disorders and Diseases of the Breast. London, Bailliere Tindall, 1989, pp. 59-73.
8 Newman J, Kahn LB: Infarction of fibroadenoma of the breast. Br J Surg 1973;60:738-40.

$\checkmark$ Lucey JJ: Spontaneous infarction of the breast. J Clin Pathol 1975;28:937-43.

10 Majinudar B, Rosales-Quintana S: Infarction of breast fibroadenomas during pregnancy. JAMA 1975;231:963-64.

11 Deshpande KM, Deshpande AH, Raut WK, Lele VR, Bobhate SK: Diagnostic difficulties in spontaneous infarction of a fibroadenoma in an adolescent: case report. Diagn Cytopathol 2002;26:26-8. 